\title{
Analysis of Gender Roles and Production Function of Small Scale Oil-Palm Processing in South-East, Nigeria
}

\author{
Nzeakor F. C ${ }^{1}$, Umeh O. J. ${ }^{2}$ \\ ${ }^{1 \& 2}$ Department of Rural Sociology and Extension \\ Michael Okpara University of Agriculture Umudike, Nigeria
}

*Corresponding Author: Umeh O. J., Department of Rural Sociology and Extension, Michael Okpara University of Agriculture Umudike, Nigeria

\begin{abstract}
This work analyzed the gender roles and production function of small scale oil palm processing in south east, Nigeria. The work employed both purposive and random sampling technique in the selection of a sample size of 224 respondents half (112) of which were males and the other half females. Data were collected using questionnaire and were analyzed with analytical instrument such as descriptive statistics and log linear regression. The result from the findings showed majority (100\%, 75\%, and $82.1 \%)$ of the male played major role in palm fruit harvesting, softening of the fruit flesh, and pressing out of the oil respectively while the female role included cracking of nut, separation of the nuts grading of the product, and head portage where $84.7 \%, 89.2 \%, 76.3 \%$, and 79.3 respectively played major roles. The stochastic production function showed that quantity of palm fruits, cost of processing capital employed was positively related to the output of both male and female processor. Whereas marital status is significant and positively related to production output of female, is not significant in male, and mill size is significant and positively related to the production output of males but not significant for females. The study recommended that Government and commercial banks should make Loans available and accessible to farmers to boost their capital as capital invested was seen to have a positive influence on output of the production.
\end{abstract}

Keywords: Gender, Roles Production function

\section{INTRODUCTION}

Agriculture in Africa is considered basically men's occupation. Women come in only to assist their husbands with farm work (Botswana Ministry of Agriculture, (BMA), (2008). The expectation of Agricultural Extension services is also that the male should answer and make decisions concerning the household farming activities. According to BMA (2008), the oldest agricultural training college in Botswana concentrated mostly on the training of males in the belief that agriculture is for men. But this scenario is fast changing. Women are increasingly becoming major stakeholders in agricultural production in most developing countries. In Uganda, the ratio of male to female workers in agriculture is estimated at 1:1.5 with women contributing seventy to seventy-five percent of agricultural labour (Opio, 2003). According to the Mickey Leland International Hunger Fellow Program (MLIHFP), (2011), women play predominant roles in the production of food staples and in household nutrition. Women-owned businesses are becoming increasingly prominent in food packaging and processing industries (MLIHFP, 2011). The Commonwealth Secretariat (CWS) (2001) in an attempt to point out the prominence of women in agriculture coined the phrase "the African farmer and her husband". The Secretariat attributes eighty percent of food production to women adding that women work more hours in food production than men. In reality women and men are engaged in agricultural production. According to Ezumah and Didomanic (1995), there has been a shift in conventional roles in agricultural labour and labour force in agricultural production, processing and marketing among Igbo women of Nigeria due to increased participation of Igbo men in the non-farm activities and wage employment. The various roles played by men and women in agricultural production are usually not clearly delineated. This is because the roles overlap and although some forms of division of labour exists, most farming activities are jointly performed. There are however agricultural activities where men dominate and which are considered suitable for men. There are others where women are the major players. According to Obinna (2011) cited in Nwachukwu (2013), women dominate in 
Analysis of Gender Roles and Production Function of Small Scale Oil-Palm Processing in South-East, Nigeria

processing of agricultural produce like oil palm and in the cultivation of crops like cocoyam and cassava while men dominate in yam cultivation and in rearing of livestock.

The role of gender mainstreaming is of utmost importance when issues concerning agriculture are discussed. Opio (2003) opines that gender mainstreaming is cardinal in the effort to be able to alleviate rural poverty, promote household food security and increase productivity in the agricultural sector. In recent years, there has been increased awareness of the need to integrate women into mainstream development efforts. The objective behind this approach is that the full use of productive potential of human resources (male and female), cannot be realized if women, who make substantial contributions to food output do not have adequate access to resources, productivity enhancing inputs and services (FAO, 2004; Akpabio, 2005).

In view of the shift in conventional roles in agricultural labour in recent time, this study seek to ascertain the current gender roles in oil palm processing with the following specific objectives

1. identify the gender role in oil palm production and

2. ascertain the production function of oil palm processing in the study area.

\section{Methodology}

This study was conducted in South East agro-ecological zone of Nigeria. Two states in the zone were purposively selected for this study based on proximity to the researcher. They are Abia and Imo states. Two agricultural zones were purposively selected from each of the two states giving a total of four (4) agricultural zones for the study. Owerri and Orlu agricultural zones were selected in Imo State; while Umuahia and Ohafia agricultural zones were used in Abia State. These zones were chosen because evidence shows that oil palm production, palm fruit processing abound in these areas (Abia State ADP Newsletter, 2006). Two blocks were purposively selected from each agricultural zone to give a total of eight (8) blocks for the study. Two (2) circles were selected randomly from each block making a total of sixteen (16) circles. One sub circle was selected at random from each circle making a total of sixteen (16) sub circles. Finally, fourteen (14) respondents were randomly selected from each of the sub circles. The fourteen respondents were made up of seven (7) male oil palm fruit processors and seven (7) female processors this gave a total of two hundred and twentyfour (224) respondents. Data were collected using questionnaire and analyzed using descriptive and inferential statistics (palm oil stochastic production function). The log linear model is as shown.

$\mathrm{Y}_{\mathrm{i}}=\operatorname{Inb}_{0}+\mathrm{b}_{1} \operatorname{In} \mathrm{X}_{1}+\mathrm{b}_{2} \operatorname{In} \mathrm{X}_{2}+\mathrm{b}_{3} \operatorname{In} \mathrm{X}_{3}+\mathrm{b}_{4} \operatorname{In} \mathrm{X}_{4}+\mathrm{b}_{5} \operatorname{In} \mathrm{X}_{5}+\mathrm{b}_{6} \operatorname{In} \mathrm{X}_{6}+\mathrm{b}_{7} \operatorname{In} \mathrm{X}_{7}+\mathrm{V}_{\mathrm{i}}-\mathrm{U}_{\mathrm{i}}$

Where:

In $=$ the natural logarithm

$\mathrm{i}=$ Processor group; $1=$ male, and $0=$ female

$\mathrm{Y}=$ Actual output of palm oil in litres

$\mathrm{X}_{1}=$ Quantity of palm fruits $(\mathrm{kg})$

$\mathrm{X}_{2}=$ Cost of hiring mill (naira)

$\mathrm{X}_{3}=$ Value of family labour in Naira

$\mathrm{X}_{4}=$ Other inputs like amount of water, transportation cost, firewood, etc used (naira)

$\mathrm{X}_{5}=$ Capital employed ( $)$ made up of depreciation on equipment and facilities, interest paid, rent

$\mathrm{X}_{6}=$ Mill size in litres/processing

$\mathrm{X}_{7}=$ Cost of hired labour in Naira

$\mathrm{B}_{0}=$ The intercept

$b_{1}-b_{6}=$ coefficients of the parameters to be estimated.

\section{RESULTS AND DiSCUSSION}

\section{Gender specific roles in oil palm processing}

The specific roles (tasks) performed by male and female in oil palm processing were analyzed, the result is presented in Table 1. 
Analysis of Gender Roles and Production Function of Small Scale Oil-Palm Processing in South-East, Nigeria

Table 1. Frequency distribution of the specific roles played by males and females in oil palm fruit processing in the study area

\begin{tabular}{|c|l|l|l|l|l|}
\hline S/No. & Task & \multicolumn{2}{l|}{ Males* } & \multicolumn{2}{l|}{ Females* } \\
\hline 1. & Pes & $112(100)$ & - & \multicolumn{2}{l|}{ Yes } \\
\hline 2. & $\begin{array}{l}\text { Separation of individual fruit from the } \\
\text { bunch }\end{array}$ & $77(68.8)$ & $35(31.2)$ & $78(70.3)$ & $33(29.7)$ \\
\hline 3. & Softening of the fruit flesh & $84(75.0)$ & $28(25.0)$ & $70(63.1)$ & $41(36.9)$ \\
\hline 4. & Pressing out of oil & $92(82.1)$ & $20(17.9)$ & $55(49.5)$ & $56(50.5)$ \\
\hline 5. & Cracking of nuts & $44(39.3)$ & $68(60.7)$ & $94(84.7)$ & $17(15.3)$ \\
\hline 6. & Separation of nuts & $29(25.9)$ & $83(74.1)$ & $99(89.2)$ & $12(10.8)$ \\
\hline 7. & Grading of the product & $32(28.6)$ & $80(71.4)$ & $85(76.6)$ & $26(23.4)$ \\
\hline 8. & Head portage & $52(46.4)$ & $60(53.6)$ & $88(79.3)$ & $23(20.7)$ \\
\hline 9. & Storing of the product & $52(46.4)$ & $60(53.6)$ & $68(61.3)$ & $43(38.7)$ \\
\hline
\end{tabular}

Source: Field survey, 2013.

Figures in parenthesis are in percentage.

*multiple responses recorded.

The result in Table 1 shows that males were more involved in such activities as: harvesting of the palm fruits from the farm, softening of fruit flesh and pressing out oil from the palm fruit. Females however dominated in the following activities: cracking of nuts, separation of nuts, head portage, grading of the product and storing of product. The females also had a slight dominance over males in separation of individual fruit from bunch. It can be adduced from the result that males dominate the more tasking activities in oil palm processing and this may be as a result of their being stronger physically than females. Also, cultural practices may also be responsible for the almost total exclusion of women from an activity like harvesting of palm fruit. It can also be pointed out that the activities where men dominate are those not needing any particular skill to execute. The activities dominated by women are the less tasking ones. They are also tasks requiring skill, carefulness, patience and focus. In all, about sixty-seven (67) percent of the activities involved in the processing of oil palm fruit are performed by females, while just thirty-three (33) percent are performed by males. This result agrees with the findings of Mejeha and Kalu (2000) who also asserted the very important roles females play as source of labour for oil palm and palm kernel processing. Furthermore, this finding clearly delineates the roles of male and female gender in the processing of oil palm fruit and lends itself to the possibility of introducing gender specific technology for the various activities.

\section{Production function of male and female processors of oil palm}

The Maximum Likelihood Estimates of the Cobb-Douglas Stochastic Frontier Production for male and female Oil Palm processors were estimated and the result is presented in Table 2. The gamma and sigma were significant at one percent alpha level implying goodness of fit and correctness of the specified assumption of the composite error distribution Okoye and Onyenweaku (2007) and Kadurumba et al. (2009). The gamma value also indicates that about 91 percent of the variability in output of male processors and 92 percent of the variability in the output of the female processors was accounted for by the efficiency factors. The result is presented in Table 2

Table2. Maximum Likelihood estimates of Cobb-Douglas Stochastic Production Function for Palm Oil Processing in the study area

\begin{tabular}{|l|l|l|}
\hline Variable & Coefficients(Male processors) & Coefficients(Female processors) \\
\hline Constant & $0.395(5.439)^{* * *}$ & $0.5132(2.278)^{* *}$ \\
\hline Quantity of palm fruits & $0.0225(2.996)^{* * *}$ & $0.0007(2.649)^{* *}$ \\
\hline Cost of processing & $0.5197(4.317)^{* * *}$ & $0.4409(5.439)^{* * *}$ \\
\hline Value of family labour & $-0.281(-0.687)$ & $0.8171(0.1541)$ \\
\hline Other inputs cost & $0.0095(-0.818)$ & $0.658(1.193)$ \\
\hline Capital employed & $0.609(2.293)^{* *}$ & $0.833(2.230)^{* *}$ \\
\hline Mill size & $0.0128(3.264)^{* * *}$ & $0.0731(1.485)$ \\
\hline Cost of hired labour & $0.189(1.168)$ & $0.1241(0.149)$ \\
\hline Efficiency value & & \\
\hline
\end{tabular}


Analysis of Gender Roles and Production Function of Small Scale Oil-Palm Processing in South-East, Nigeria

\begin{tabular}{|l|l|l|}
\hline \hline Age of farmer & $-0.0241(-2.219)^{* *}$ & $-0.0246(-6.977)^{* * *}$ \\
\hline Household size & $0.123(5.648)^{* * *}$ & $-0.093(-0.810)$ \\
\hline Level of Education & $0.0606(5.643)^{* * *}$ & $0.1064(3.855)^{* * *}$ \\
\hline Processing Experience & $0.0191(2.082)^{* *}$ & $0.135(2.217)^{* *}$ \\
\hline Membership of Cooperative & $-0.0131(-0.491)$ & $0.138(0.046)$ \\
\hline Amount of credit obtained & $0.013(2.534)^{* *}$ & $0.082(5.068)^{* * *}$ \\
\hline Extension contact & $0.024(0.422)$ & $-0.0270(-1.015)$ \\
\hline Processing method & $0.704(2.863)^{* * *}$ & $0.1661(5.654)^{* * *}$ \\
\hline Marital status & $0.2876(1.436)$ & $0.013(2.534)^{* *}$ \\
\hline Diagnostic statistics & & \\
\hline Sigma-square $\left(\delta^{2}\right)$ & $1.7268(6.775)^{* * *}$ & $1.5556(6.329)^{* * *}$ \\
\hline Gamma $(\lambda)$ & $0.9078(27.658)^{* * *}$ & $0.9235(26.789)^{* * *}$ \\
\hline Log-Likelihood & 96.8615 & 99.2692 \\
\hline LR Test & 30.2768 & 28.8271 \\
\hline
\end{tabular}

Note: Asterisk $* * *$ and $* *$ represent $1 \%$ and 5\% significance levels respectively. Figures in parenthesis are $\mathrm{t}$ value.

Source: Field Survey, 2013.

Table 2 shows that for the production factors, the coefficients of quantity of palm fruits used in processing, cost of processing, mill size and capital employed were significant factors that affected the output (quantity of palm oil produced ) of the male oil processors.

The coefficient of quantity of palm fruit used in processing was significant at one percent and positively related to output of palm oil. This agrees with aproiri expectation and implies that the more the quantity of palm fruit used in processing, the more the quantity of palm oil produced. Thus increase in the supply of palm fruits will invariably lead to an increase in the volume of palm oil that is produced. This can be attributed to the fact that the palm fruit is the single most important factor in processing as it is from the palm fruit that the oil is gotten. According to Mohd (2002), the output of processing mills in terms of quantity of palm oil produced is correlated to the quantity of fresh fruit bunches used in the processing and hence the profit made from processing. This result also agrees with Kadurumba et al. (2009).

The coefficient of cost of processing was significant at one percent alpha level and positively related to output of the processor. This relationship implies that the higher the output produced by the processor, the higher the cost incurred. This result does not agree with apriori expectation and may be due to inefficiencies in the milling process or in the utilization of resources.

The coefficient of mill size was significant at one percent alpha level and positively related to the output of the male processors. The implication of this direct relationship is that the larger the mill size the higher the quantity of palm oil that will be produced. This agrees with aproiri expectation and may be attributed to the fact that the size or capacity of the mill inevitably determines what the output from it will be. Therefore a small mill size will definitely produce small amount of oil, while large mill will produce a higher volume of oil. The implication of small mill size producing smaller quantity of oil is more obvious in the case of the traditional presses with their very small capacity and hence very low output. WRM (2001) reported that the traditional small size mills apart from their low output, are mostly associated with the problems of low efficiency and low extraction rate.

The coefficient of capital employed was significant at five percent alpha level and positively related to quantity of palm oil produced. This implies that the higher the capital invested in oil palm processing the more the quantity of palm oil produced. This is because the more the capital used in processing in terms of funds, improved processing facilities and equipment the higher the efficiency of the processor and hence the higher his output. The male processors as would be expected are more endowed financially to make substantial investments in their processing activities and hence the more their output. This result agrees with Kaine (2011) who noted that the more the investment made on processing equipment the higher the output.

Other non significant factors which affected the output of male palm oil processors included: cost of hired labour which was positively related to output; value of family labour and other inputs cost which were negatively related to output. 
Analysis of Gender Roles and Production Function of Small Scale Oil-Palm Processing in South-East, Nigeria

For female processors, the result shows that the coefficients of cost of processing, quantity of fruits, and capital employed were significant factors that affected output of palm oil.

The coefficient of quantity of fruits used in processing was significant at five percent alpha level and positively related to quantity of palm oil produced. The implication of this result has been discussed above.

The coefficient of capital employed was significant at five percent alpha level and positively related to output of palm oil. The implication of this relationship has been discussed earlier.

Other non-significant factors that affected the output of female oil palm processors included: other inputs cost, mill size, value of family labour and cost of hire labour which were all positively related to output.

For the efficiency factors, the following variables significantly affected the output of male processors: household size, processing method, level of education, age of the processor, processing experience and amount of credit obtained.

The coefficient of household size was significant at one percent alpha level and positively related to the output of the processor. This implies that the larger the household size of the processor, the more his output of palm oil. This positive relationship may be attributed to fact that a large farm household may mean the ready availability of more labour for use in the farm or for processing of farm produce. Thus the processing activities of those processors with large household size would be less strenuous and more efficient because there are more hands to do the work. The efficiency and output of a large household would be further enhanced if there are more experienced household members engaged in the processing.

The coefficient of level of education was significant at one percent and positively related to output of the processor. This relationship implies that the more educated the processor, the more efficient he would be in processing and thus the higher would be his output. This may be attributed to the fact that the educated processor would be better equipped to handle and manage properly his processing activities. The educated processor would also be better positioned to seize the opportunity of improved processing technology to improve his processing efficiency and thus his output while also taking advantage of the availability of credit facilities and other resources to expand his business. This result agrees with Onyebinama (2001) who asserted that higher levels of literacy increase the ability of farmers to cope with the complexities of new technologies and the intricacies of new product and factor markets.

The coefficient of processing method was significant at one percent and positively related to the output of the processor. This direct relationship means processors who use modern (improve) processing methods are more efficient and produce more than those who use the traditional processing method. This agrees with aproiri expectation and may be attributed to the higher efficiency, higher extractive ability, larger capacity and less drudgery that the modern technology affords the processor. All these combine to make the output from such process higher than that of the smaller traditional process. This result agrees with WRM (2001) and Mohd (2002) both of whom reported similar results in their work.

The coefficient of processing experience was significant at five percent alpha level and positively related to output of the processor. This direct relationship implies that the more experienced the processing, the higher would be his output and may be accounted for by the fact that the experience processor will always fall back on his wealth of experience to overcome the challenges and constraints that may arise during his processing activity. Nwaru (2004) agrees with this position, noting that the number of years a farmer has spent in the farming business may give an indication of practical knowledge he has acquired on how he could overcome certain inherent farm production challenges.

The coefficient of amount of credit was significant at five percent and positively related to output of the processor. This implies that the more the amount of credit the processor is able to access the higher would be his output. This direct positive relationship may be attributed to fact that credit has the ability to act as a catalyst for enhanced capacity utilization and hence increased output. Thus the processor who is able to access a sizeable amount of credit is better positioned to improve and 
Analysis of Gender Roles and Production Function of Small Scale Oil-Palm Processing in South-East, Nigeria

increase his processing activity through the acquisition of better technology and inputs. Oboh and Kushwaha, (2009) have noted that credit has the ability of transforming smallholder agriculture from subsistence orientation to market orientation. This result is consistent with the findings of Nwaru (2004) and Kadurumba et al. (2009) who reported similar findings in their work.

The coefficient of the processors age was significant at five percent alpha level and negatively related to his output. This implies that the older the processor, the lower his output. This negative relationship may be accounted for by the fact that the aging processor may not be able to perform his processing activities efficiently considering the fact that most activities in the processing of oil palm fruit are quite exerting and strenuous. Elderly processors who use traditional oil presses are more disadvantaged because of the drudgery and stress associated with the process.

For the female processors, the efficiency factors were: household size, processing method, level of education, age of the processor, processing experience, amount of credit obtained and marital status. The implications of the relationships between output and these variables except marital status have been discussed earlier.

The coefficient of marital status was significant at five percent alpha and positively related to output. This result implies that a married processor produces a higher output than one who is not married. This direct relationship may be accounted for by the fact that the married processor has the spouse to assist her in her processing either directly by providing labour, or indirectly by providing funds which could be use to run or expand the business. Also, the married processor may also have a household with members who could help her in her processing activities and thus contribute to increase her output.

\section{CONCLUSION AND RECOMMENDATIONS}

Based on the finding of the study concluded that the major role of male oil palm processors included harvesting of the palm fruits from the farm, softening of the fruit flesh, and pressing out oil from the fruit whereas the female major roles included cracking of nuts, separation of nuts, head portage, grading of the product and storing of product. The study also quantity of palm fruits used in processing, cost of processing, mill size and capital employed were significant factors that affected the output (quantity of palm oil produced) of the male and female oil processors, and that marital status are major factor that affection female oil production. Based on this conclusion the study makes the following recommendation

1. Female oil palm processor should be given incentive to invest in a large scale production as they play significant role in oil palm production.

2. Cultural laws and government policy should be made in such a way to allow unmarried women to strive as the study showed that married women were likely to have a higher production output than the unmarried.

3. Government and commercial banks should make Loans available and accessible to farmers to boost their capital as capital invested was seen to have a positive influence on output of the production.

\section{REFERENCES}

Abia State Agricultural Development Programme (ADP) (2006). Newsletter.

Akpabio, I.A. (2005). "Human Agriculture: Social Themes in Agricultural Development, Uyo: Abam Publishing Company. Pp 101.

Botswana Ministry of Agriculture (BMA) (2008). "Gender and Agriculture". A Policy Paper Prepared by Monitoring and Evaluation Unit; Agricultural Planning and Statistics for Women's Major Group Commission on Sustainable Development Summit on Cycles 16 and 17, July 26, 2008.

Common Wealth Secretariat (CWS) (2001). "Women's Role in Economic Development. Earlysana Publication Ltd. London pp 2-15.

Ezumah, N.N. and Difomanic, C.M. (1995). "Enhancing the Role of Women in Crop Production. A Case Study of Igbo Women in Nigeria". World Development vol. 10.pp 1731-1744.

F.A.O. (2004). "Oil palm in Western Kenya". FAO A.C. 21 Magazine. Pp. 1-3. 
Analysis of Gender Roles and Production Function of Small Scale Oil-Palm Processing in South-East, Nigeria

Kadurumba, C., C.I. Ezeh and J.A. Mbanasor (2009). "Technical Efficiency of Traditional Palm Oil Processing in Imo State, Nigeria. Proceedings of $23^{\text {rd }}$ Annual Conference of the Farm Management Association of Nigeria.

Kaine, A.I.N. (2011). "Investigation of Factors Affecting Technical Efficiency of Akpu Processing in Delta State, Nigeria". Journal of Human Development (33):2, 133-137.

Mejeha, R.O. and Kalu, K.O. (2000). “ Gender Role in Palm Fruit Processing: Implications for Rural Poverty Alleviation". Food and Fibre Production in Nigeria, 10-13 ${ }^{\text {th }}$ September, 2000 Umuahia.

MLIHFP (2011). "Effective Gender Mainstreaming in Agriculture for Secure Household Nutrition". Mickey Leland International Hunger Fellows Program Policy Paper.

Mohd, A.S. (2002). "Factors Affecting Fluctuations in Net Returns from the Processing of Oil Palm Bunches". Oil Palm Industry Economic Journal Vol2 (1):28-33.

Nwachukwu, I. (2013). Agricultural Extension and Rural Development; Promoting Indigenous Knowledge. Umuahia, Lamb House Publication, P.113-141.

Nwaru, J.C. (2004). "Gender and relative production efficiency in food crop farming in Abia state on Nigeria". The Nigerian Agricultural Journal, Vol. 34, Pp 1-10.

Oboh, V.U. and S. Kushwaha. (2009). Socio-economic determinants of farmer's loan size in Benue state, Nigeria. Journal of Applied Sciences Research. 5(4): 354-358.

Okoye B.C. and Onyenweaku C.E. (2007) Economic Efficiency of Small-holder Cocoyam Farmers in Anambra state, Nigeria: A Translog Stochastic Frontier Cost Function Approach. Medwell Online Agricultural Journal ANSL net Building, 308-Lajani Town, Saraodha Roal, Falsalbad, Pakistan 2 (2): 535-542.

Onyebinama U.A. U. (2001)."An Analysis of the Prospect for Commercialization of Smallholder Agriculture in Imo State. Journal of Agricultural Technology 9(2): 50-58.

Opio, F. (2003). "Gender Mainstreaming in Agriculture with Special Reference to Uganda: Challenges and Prospects”. African Crop Science Conference Proceedings Vol. 6. 699-703.

WRM (2001). "Nigeria: Palm Oil Deficit in a Palm Oil Producing Country”. WRM Bulletin No. 47. June, 2001.

Citation: F. C Nzeakor, O. J. Umeh, " Analysis of Gender Roles and Production Function of Small Scale Oil-Palm Processing in South-East, Nigeria ", International Journal of Advanced Research in Botany, vol. 4, no. 1, p. 7-13, 2018. http://dx.doi.org/10.20431/2455-4316.0401002

Copyright: (C) 2018 Authors. This is an open-access article distributed under the terms of the Creative Commons Attribution License, which permits unrestricted use, distribution, and reproduction in any medium, provided the original author and source are credited. 